\title{
Construction of atrium in the Tula Kremlin: history, background and opportunities
}

\author{
Olga Pastukh ${ }^{1, *}$, Andrey Vaitens ${ }^{1}$ and Svetlana Golovina ${ }^{1}$ \\ ${ }^{1}$ Saint-Petersburg State University of Architecture and Civil Engineering, 4, 2nd Krasnoarmeiskaya \\ st., 190005, St. Petersburg, Russia
}

\begin{abstract}
The possibility of partial renovation of the historical center of Tula - Tula Kremlin is discussed. The formation of atrium space in the North-Western part of the Kremlin is considered. This conversion recreates the lost historical integrity of the ancient ensemble and creates new possibilities of use of the historic center of the ancient Russian town. Initially, the urban space of the Tula Kremlin was limited by a wall, but with the lapse of time, the city went beyond that boundary. Initially, the Kremlin had all the fullness of urban functions, but the majority of these functions have been gradually lost, it evolved primarily in a large public center, and nowadays it has become an object of museum-tourist destination. The concept of "Kremlin" includes as a mandatory component outlined urban space, formation of which complies its own laws in the interaction of many different factors: system of spatial and visual relations, temples, city gates and towers. The reconstruction of historic integrity of ancient ensembles was begun within the framework of the Federal State Program, possible ways of its recovery are considered.
\end{abstract}

\section{Introduction}

The aim of this study is to identify and analyze features and patterns of architectural and planning development of the Tula Kremlin.

Problems:

1. Collect, systematize and study project materials and historical documents on the formation of the Tula Kremlin territory;

2. To investigate the peculiarities of architecture and planning structure of the studied space;

3. To study the influence of an industrial facility located in the Kremlin on the spatial shape of its internal space;

4. To conduct comparative analysis of the various stages of the formation of the Kremlin space;

5. To reveal the general regularities of transformation of the considered territory;

6. Consider the possibility of further introduction of new facilities in the space-planning structure of the Tula Kremlin.

The methodological basis of this study:

\footnotetext{
* Corresponding author: gvolia@yandex.ru
} 
1. Historical and compositional comparative analysis of the architectural and planning structure of the Kremlin at different stages of its formation;

2.Problem-logical method of analysis of transformation of the architectural and planning structure of the Tula Kremlin;

3. Method of historical analogies and comparative analysis of foreign practice of incorporating modern facilities in historic environment;

4. Method of social adaptation and increase of social significance of the historical monument through attraction of possible investments and increase of tourist attractiveness.

In this case these methods are the most appropriate. Since the Kremlin is the core of a historical settlement, all changes that occurred to it over a long period of time (many centuries since its foundation) were carried out within the territory limited by the Kremlin walls, without going beyond it [1] .

This article proves the possibility of including a new object in the "living tissue" of the internal space of the Tula Kremlin. Parallels are drawn with similar solutions of new construction in France - Mont Saint Michel castle island and in Austria is the Vienna gasometers, located in Vienna, built in 1896-1899. In 1999-2001 they were rebuilt and became a multi-functional complex (Gasometer Vienna) [2].

\section{History of formation of the Tula}

Tula is first mentioned in a chronicle from 1146 as a riverside settlement protecting the boundaries of the Moscow state. A small town (approximately 2,5 hectares) at the confluence of the rivers Tulitsa and Upa, which is a right-bank inflow of the Oka river. Architectural and spatial features of the historic center of Tula were brought about by its low location in the floodplain of the Upa river. Though all main highways along which the town developed originate from the Kremlin, the "heart" of the city remains "hidden" in the lowland. Stages of the city development:

1. In the 15 th century Tula was the first Russian town on the trade route under the name "Muravinsky Trail ". It was the main direction of the Crimean Tatars invasion into the Moscow principality.

2. At the beginning of the 16th century a fortress on Zasechny line is under construction - a stone Kremlin. It enclosed the ancient settlement and part of the Kremlin with its strengthened walls. A wooden jail of crescent form appeared shortly after, occupying a significant territory. Later semicircular wooden jail appeared which embraced considerable territory from three sides from the Kremlin, which low-lying arrangement is unique for the practice of domestic town-planning [3].

3. From the 16th to the 17th century Tula developed as a trade and craftsmen center with a large number of craftsmen settlements located along the roads leading to the town. By the end of the 16th century between the potter's (Goncharnaya) settlement and the river, northwest of the road to Moscow, the blacksmith's Kuznetskaya (Armoury) settlement appeared.

4. In the second half of the 17 th century the settlement of Chulkovo, separated from Zarechie by the floodplain of the river Tulitsa, was created. It permanently defined the threepart structure of the town, and the town further expansion was due to the development of the Left bank regions, Zarechie (Weapon settlement) and Chulkovo (Fig. 1). 


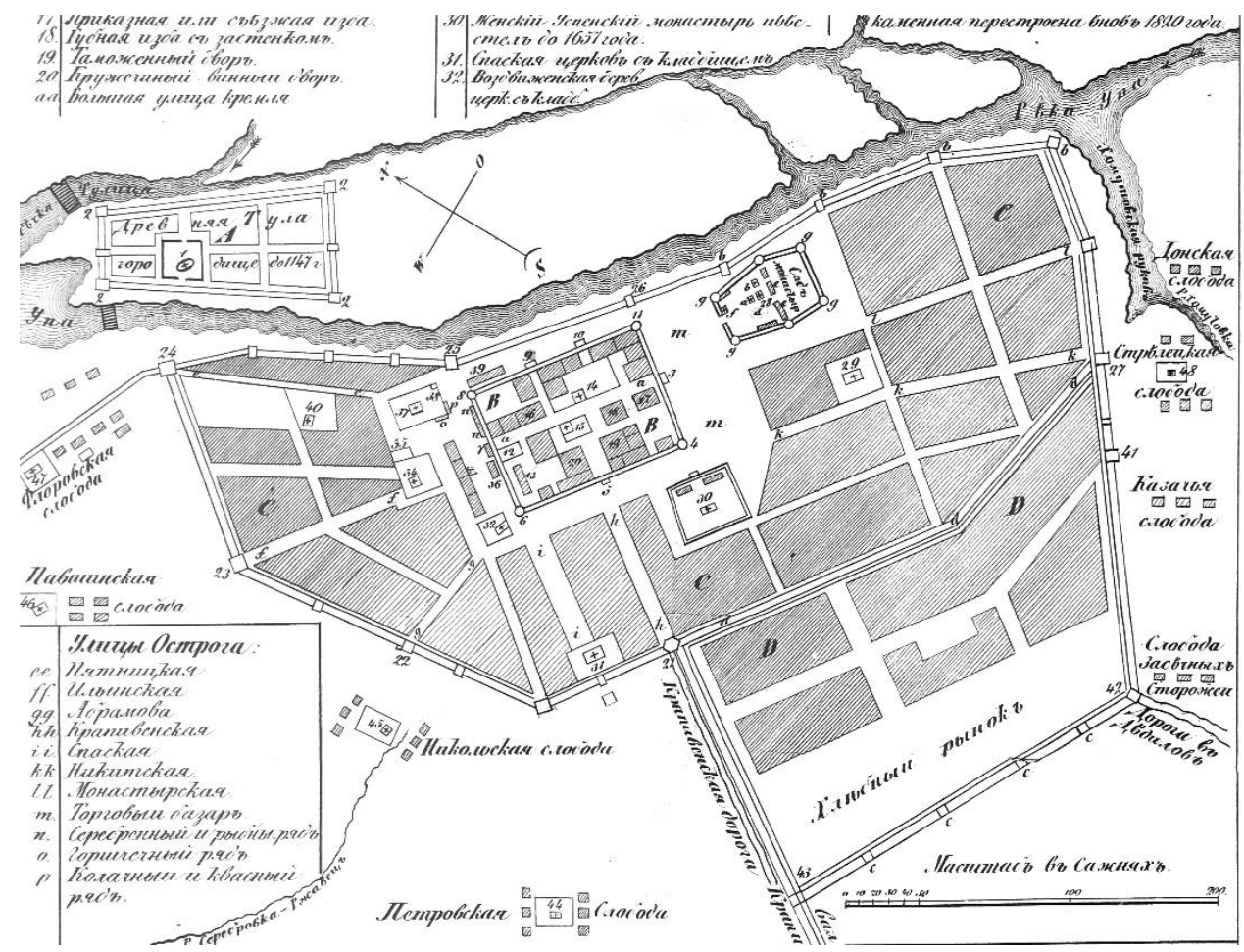

Fig. 1. Plan of the fortresses of Tula based on the historical survey of the Tula province by I. Afremov restored according to the inventories of 1625 and 1685.

5. The first half of the 18th century witnessed the first ideas of re-planning Tula on a regular basis. The ideas of rectangular districts remained urgent when developing the regular plan of Tula in 1779, which became, in fact, the first master plan of the town development. According to that plan, the center was assigned to the Kremlin, which was planned to be reconstructed based on the classical principles of strict regularity. Architectural and spatial features of the historic center of Tula are caused by its low-lying arrangement in the floodplain of the river. All main highways along which then town developed originated from the Kremlin.

6. Up to the beginning of the 20th century, the historically established centripetal nature of the town's plan remained intact. On the Left bank part of the town Kiyevskaya Street (Lenin Av.) runs to the south from the Kremlin, it became the central axis of symmetry. Also in the central part two radial axes were allocated: the Vozdvizhenskaya (Revolyutsii St.) and Voronezh (Oboronnaya St.) Streets. All of them are focused towards the Assumption Cathedral bell tower in the Kremlin and "hold" the composition of the planned grid of streets in the Left bank region which has a pronounced radial and arc character. Both right-bank regions - Zarechie and Chulkovo - have a rectangular grid of streets.

7. In the first years of Soviet power (1917-1930) a huge number of Orthodox churches were lost in a historical center (including the Kremlin), which destroyed the existed system of volume and space planning (fig. 2) [4]. 


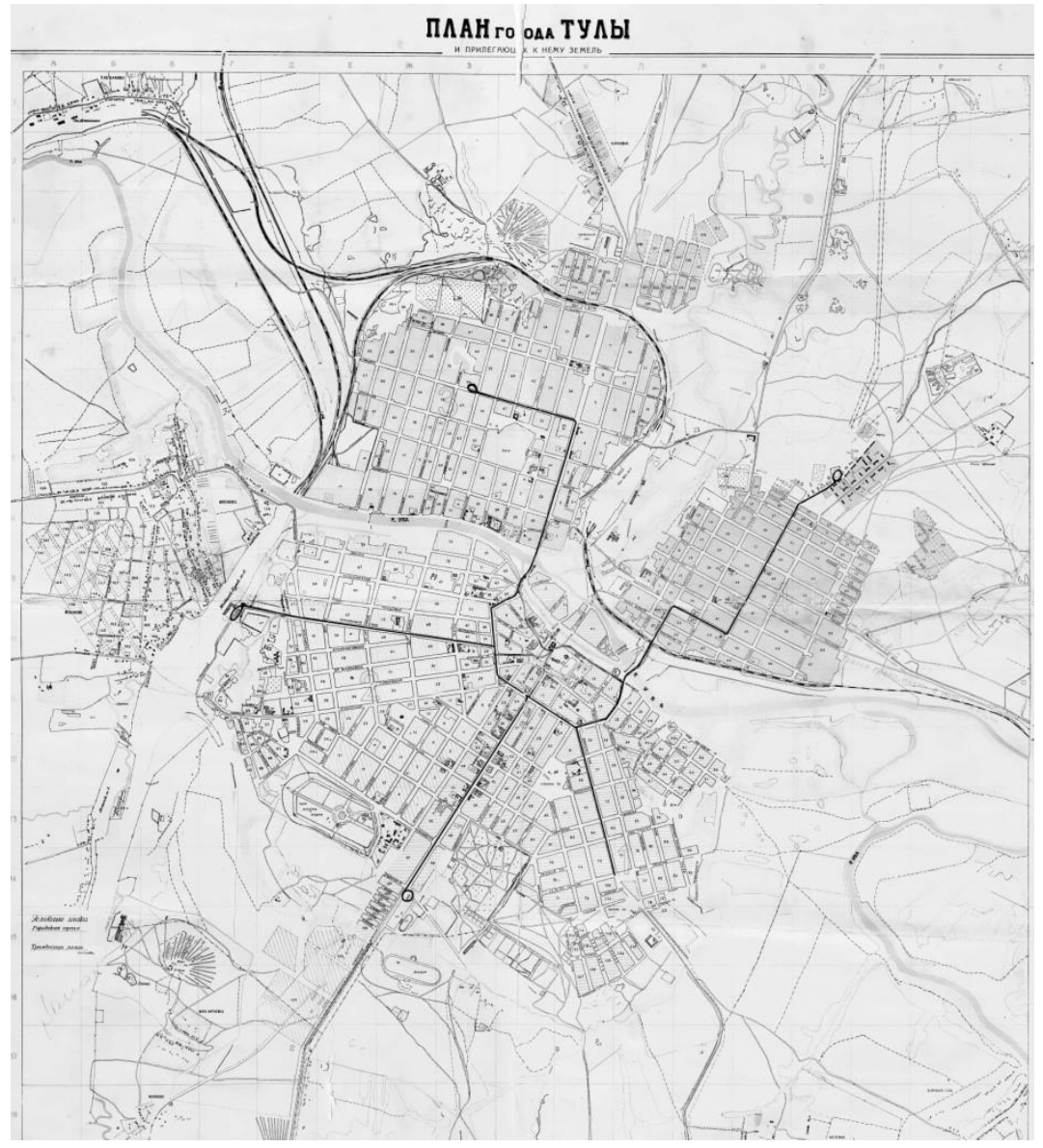

Fig. 2. City map of Tula, 1933, developed by the Land and Planning management of the Tula Municipal department according to the GGU survey of 1929 - 1931.

8. During the Great Patriotic War (1941-1945) the town defence managed to protect the boundaries of the small homeland and minimize damage to the historical centre of the ancient town. It should be noted that during the Great Patriotic War the Tula Kremlin was damaged much less than Russia's other historical towns such as Zaraysky, Nizhny Novgorod and the Pskov Kremlin. On the contrary, much more serious damage was caused by a change of ideological and political views within the country.

9. In the 1990's specialists from the Tulskgrazhdanproyekt (Tula citizens project) organization developed the Protective Zones of Cultural Heritage Project which determined the necessary structure and borders of the protective zones. The project covered a territory which approximately corresponded to that covered by the regular plan of prerevolutionary Tula at the beginning of the $20^{\text {th }}$ century [5].

\section{The history of the formation of the internal space of the Kremlin, as background of the future transformation}

The question of the future of the Tula Kremlin and methods of its restoration arose at the beginning of the $21^{\text {st }}$ century. The Restoration to the historical integrity of the ancient ensemble began within the auspices of the state program [6, 7]. It includes restoration of the 
Kremlin cathedrals religious functions, reconstruction of the completely destroyed bell tower (2012), and the restoration of the walls and towers of the Kremlin. For many years the challenge remained of what to do with the brick buildings of Tula's first power plant built on the territory of the Kremlin at the beginning of the 20th century and which are not under the protection of the cultural heritage program (unlike the walls and towers of the Kremlin) $[8,9]$.

Before attempting to solve this problem, it is necessary to recollect what the Tula Kremlin represents, the history of its formation as well as estimate the possibility of new objects creation within its territory. Initially the town space was limited to the fortification, but eventually the town grew beyond this boundary, and then this boundary lost its defensive function and disappeared over time. Only in a few towns do the ancient citadels -Kremlins, survived, but they also did not remain invariable. Incorporating once all completeness of city functions, they gradually lost a considerable part of these functions, turning mainly into the large public centres, and in our times - into museum and tourist objects.

The Kremlin is an unchangeable Central part-the core of the historical settlement.

The Kremlin is not only fortifications and towers. The concept "Kremlin" also includes as an obligatory component the urban space outlined by them. In which a major role is assigned to town-planning and architectural dominants - temples, city gates and towers. They are basic elements of spatial composition in a continuously changing background of terraced housing. The loss of these architectural dominant structures in the general composition and the subsequent loss of the surrounding environment leads to the breaking of compositional integrity. History of the Tula Kremlin in this regard is both typical and unique. Until a certain time its territory was densely built-up, which is confirmed by the old plans as well as the reconstruction of the planned structure of the Kremlin executed in compliance with them. Two intersecting streets connecting the city gates formed the basis of this structure and divided the whole territory into four large districts, a ring detour around the fortifications and several drives for access to the yards located inside the districts. In the centre of the Kremlin, at the intersection of the two main streets there is a small square with the old Assumption Cathedral. The high density of buildings and lack of extensive open space caused the nature of visual perception of the cathedral, the Kremlin walls and towers mainly at a short distance in a considerable foreshortening that is peculiar to all medieval town planning. A special feature of Tula's Kremlin that makes it stand out from other regular, analogous structures (Zaraysk Kremlin, Pskov and Ryazan Kremlin, the Belgorod fortresses, Donskoy Monastery etc.) is the location and positioning of its cathedral [10].

The main factor in the planning of such ensembles was the geometrically correct composition of the main architectural dominant - the cathedral, located at the crossing of the main axes. The Assumption cathedral (1684-1685), built in stone and located on the axis of the Odoyevsky Gate-the citadel's main gates, was shifted closer to the opposing wall along its transverse axis. It was oriented strictly to the east as determined by the number of towers on the side of the Kremlin wall facing the river: the Odoevsky' Gate Tower here stands opposite two towers. Thus, the major spatial characteristics of the main elements of the Kremlin structures are nothing but functions of the fortification's perimeter and its high-rise accents - the towers. The city led its usual life, being constantly updated and changed [11]. From this stage, only the walls and towers remain, which were completed in the second half of the 20th century. Unfortunately It's not possible to track changes in the building of the Kremlin in the following hundred years in stages. In the middle of the 18th century construction of the new Assumption Cathedral was undertaken; the increase in scale of certain buildings including the cathedral began. It caused the expansion of the Cathedral Square and changed the spatial relations, but the general perception of the architectural dominants still remained. Therefore, the new Assumption Cathedral (1762-1764), like the old one, was located on the axis of the Odoevsky Gate tower, displaced along the tranverse axis of the whole ensemble towards the gate. A graphic analysis of the plan enables us to 
explain both the placement of the cathedral, and its orientation in space, and shows that the cathedral had grown considerably in size in comparison with the previous one.

As it was already mentioned, the orientation of the old Assumption Cathedral was determined by the direction of diagonals of the rectangular territory of the Kremlin. A Similar situation with the new Assumption Cathedral. Its western facade lies on the line leading from the arch of the Odoevsky Gate to the arch of the Water gate. The plan of the cathedral fits into the space confined by the two diagonals and two beams (two smaller roads). At the same time the line of the southern facade lies in the direction of the arch of the Ivanovo Gate tower, and the diagonal of the main volume of the cathedral marked by three domes - lies in the direction of the Nikitsky tower. Therefore, concerning this cathedral it is possible to claim that the basic spatial criteria of the arrangement and parameters of the cathedral are complex functions of the perimeter of the Kremlin walls and in particular their towers. Only the Pyatnitsky tower had kept a neutral position in relation to the cathedral, but only until the construction of the bell tower in 1772 - 1776. During reconstruction of the centre of the Kremlin, there was a considerable increase in the scale of structures built on its territory and full composition integrity of ensemble was attained, maintaining continuity in its development (fig. 3).
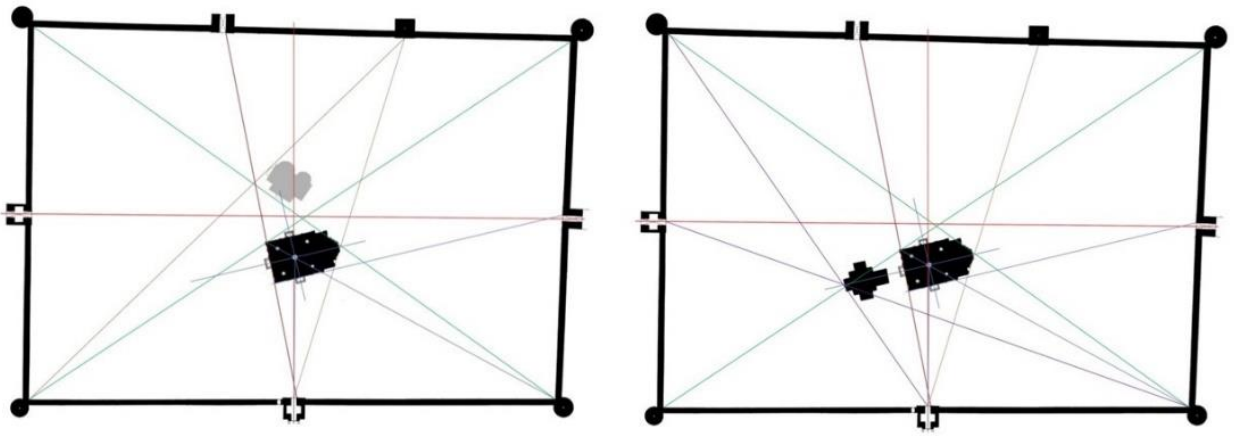

Fig. 3. Graphical layout of objects on the territory of the Kremlin in this period.

It is to this stage that we should refer the reconstruction of the Kremlin towers, which by then had no hipped roofs. As a result of the graphic analysis of the Kremlin's plan, it is obvious that the corner towers and the Odoevsky Gate tower hold the entire composition together. It was the construction of these towers at the end of the 18th century that emphasized their role in the ensemble. The forms of the towers in their new interpretation coordinated well with the form of the just constructed multilevel bell tower of the Assumption Cathedral. The towers are represented as described here on a panorama of the Kremlin based on the plan of Tula approved in 1779 and the famous engraving of 1807 (fig. 4). Only the building of the Assumption Cathedral and the superstructure of the Odoevsky Gate tower remain until nowadays from this stage in the history of the Kremlin. Sorry to say, there is no any authentic graphic data depicting the Kremlin in the 18th century. The planning and mainly wooden buildings of the previous hundred years gradually changed, but there were no drastic changes. 
a.
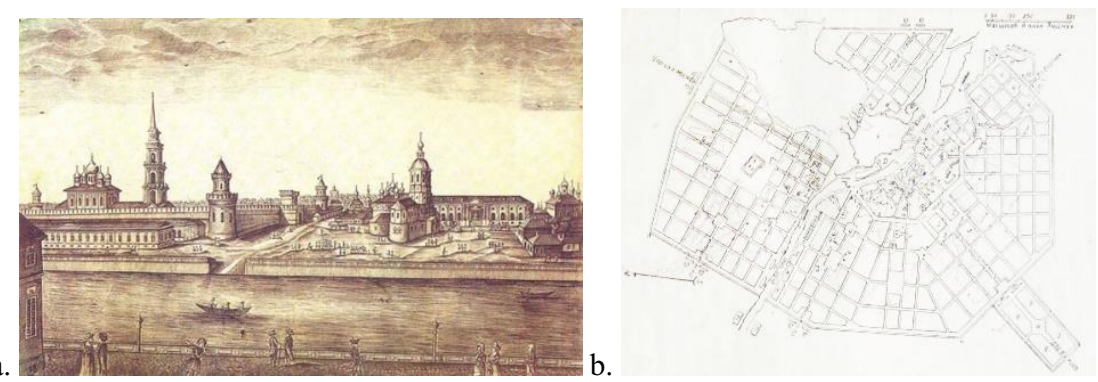

Fig. 4. a - An engraving with the image of the Tula Kremlin. 1807; b- Map of Tula 1779.

The reconstruction of the Kremlin planned according to the city plan of 1779 based on classical principles of strict regularity was not carried out. Regrettably, many other ideas were never realised. The idea to create a large square around the cathedral and just completed multilevel bell tower was never further developed, as well as the idea to move the provincial administrative centre to the Kremlin- it was later moved to the city's main road. The remains of the Trading Stalls do not play an active role in the ensemble; they only form the urban environment which is constantly changing. Nevertheless a certain scale is maintained in this change allowing its harmonious inclusion into the whole newly developed composition. The Epiphany Cathedral (1855-1862) became a new active element (fig. 5).

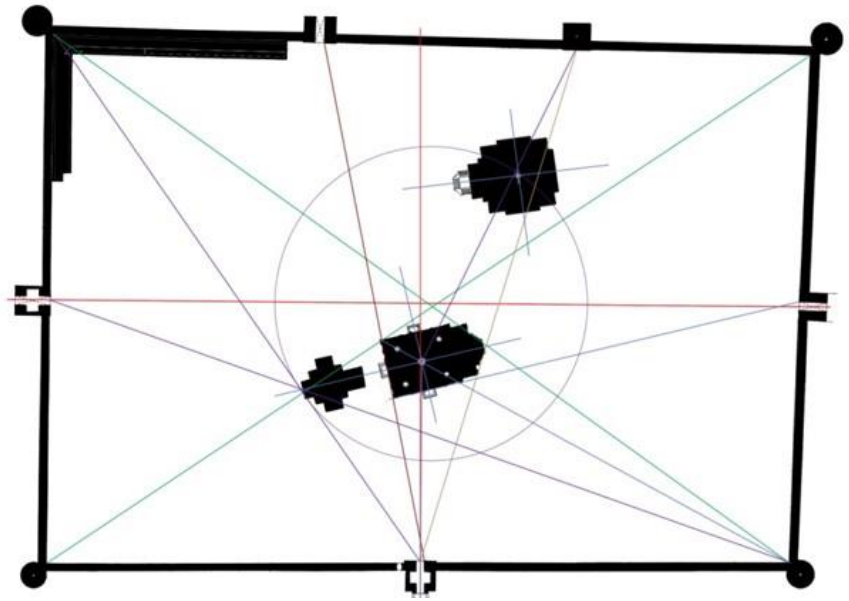

Fig. 5. Graphical layout of objects on the territory of the Kremlin in that period.

\section{The impact of industrialisation on the inner space of the Kremlin}

At the turn of the $20^{\text {th }}$ century when Tula's first power plant was constructed, the Cathedral Square where the old Assumption Cathedral once stood actually lost its value.

The power plant is located diagonally opposite the right angle in the Kremlin wall and lies on the line joining the gates of the Pyatnitsky and Water towers, analogous with the Assumption Cathedral which it faces. Contrary to its real status, but due to its location, it turned into a focal point of the whole ensemble (fig. 6). The transfer of the accent from the Cathedral Square turned out to be a direct consequence; obviously, the square fell into a subordinate state here. Thereby the spatial subordination was broken: the most active zone appeared out of the compositional centre of the Kremlin - the cathedral complex. Actually, it means loss of the architectural and spatial integrity of the ensemble. 
a.
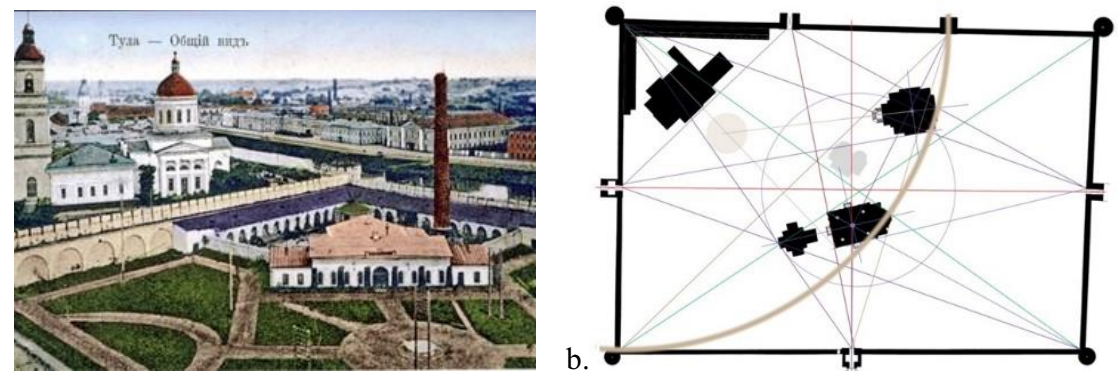

Fig. 6. a -photo of the beginning of the XX century; b - the graphical layout of the power plant on the territory of the Kremlin.

This situation did not last long. A new L-shaped block of the power plant introduced serious changes to it. Despite the simplicity of its architecture, it played an important role in the formation of the Cathedral Square, having fixed its western border. This way the broken balance was restored.

The emergence of a new block completely destroyed the square. Instead of it an inner yard formed, which so far has come to a state of total desolation as well as the buildings themselves (fig. 7).

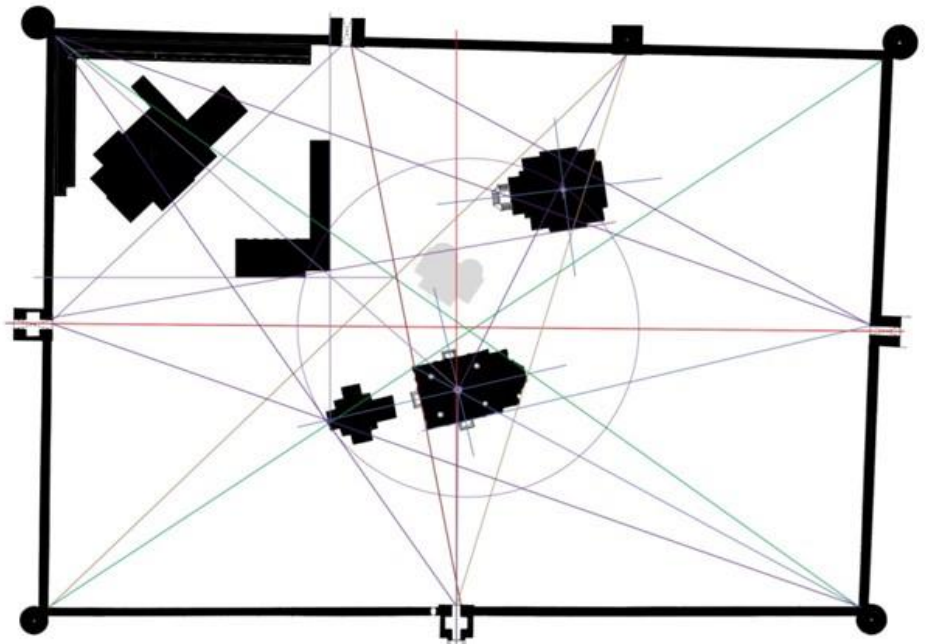

Fig. 7. Graphical layout of the power plant on the territory of the Kremlin in this period.

\section{Promising possibilities for transforming the inner space of the Kremlin}

We can consider several options for the future of the Tula Kremlin [12]. Besides the 'demolish' option, it is expedient to consider renovation and partial reconstruction of the territory. Let us consider all possible options.

\subsection{Option 1: to demolish}

There are several objections.

Firstly, the brick buildings have historical value as they are part of Tula's first power plant. Their emergence on the territory of the Kremlin is significant. Tula is an industrial 
town and one of its distinctive features is the fact that it consists of a number of large plants, including the oldest armory factory founded by Peter the Great and they are all located in the centre of the modern town, in close proximity to the Tula Kremlin. The preservation of an industrial building on the territory of an ancient citadel in this regard makes great sense (fig. 8).

Secondly, buildings of power plant occupied the space of former northwest Kremlin quarter in the correct scale to the temples existing nowadays. Clearing of this part of the Kremlin from buildings will finally turn all its territory in empty space surrounded with a stone wall.

Thirdly, only in the zone which is directly close to the power plant buildings conditions for visual perception of the Kremlin wall and the Kremlin towers at a short distance have remained till now, which is a distinctive characteristic of medieval towns with their compact planning of fortified centers $[13,14]$.

a.

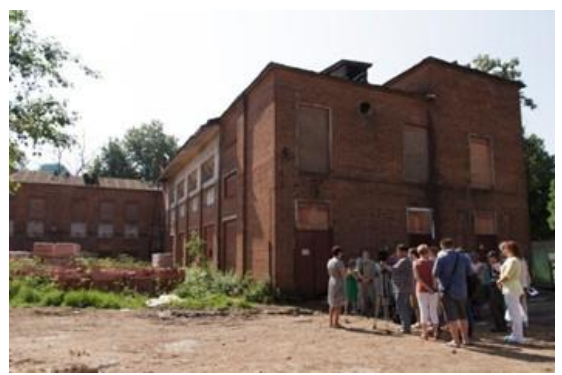

b.

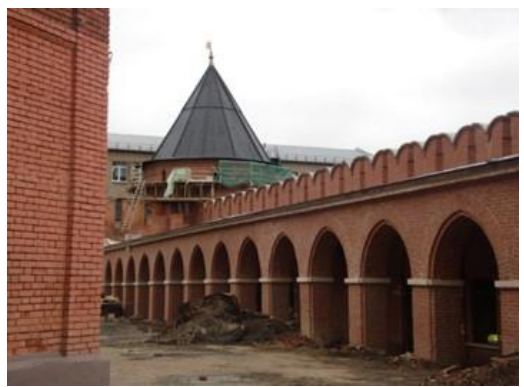

Fig. 8. a - power plant buildings; b - part of the wall of the Kremlin today.

\subsection{Option 2: to restore}

It is not advisable as the buildings which were repeatedly rebuilt and left abandoned for too long have no art value, their value is only historical.

\subsection{Option 3: to reconstruct}

This option, as a matter of fact is unique. A group of young, but already quite skilled Tula architects under the leadership of the recognized master of architecture E. V. Erzovsky came up with concrete proposals. The essence of their proposals is integration of both buildings in a united complex by overlapping the courtyard with modern large-span structures [15]. The project received the conventional name "atrium". Such courtyard, or "atrium", is the conceptual center of the project (fig. 9).

a.

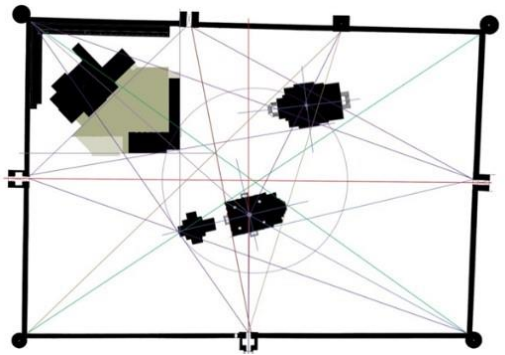

b.

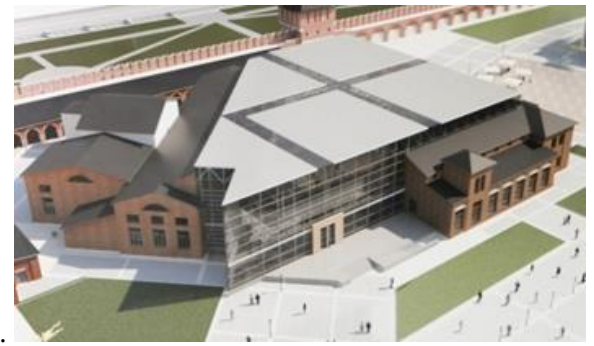

Fig. 9. a - graphical design; b - 3-d model of the project of the atrium in the Tula Kremlin. 
Search of a basic way to the problem solution and detailed development of the project have no value until the answer to the main issue - a question of an inclusiveness of "atrium" in spatial structure of an architectural complex of the Tula Kremlin is received. The solution proposed by authors of "atrium" does not break the system of historically developed spatial relations of all elements of the ensemble: the plan of "atrium" completely fits into this system, entirely submitting to its internal logic. Simple, laconic means are used to achieve integration of constructions of the $20^{\text {th }}$ century, their matching to each other and to the close environment [16]. Use of modern large-span designs in overall ceiling and modern materials, first of all glass, in decoration of facades allowed to keep at objects reconstruction, in the transformed way, both the idea of courtyard itself, and feature of this yard - its spatial orientation to the Kremlin towers.

\section{Conclusions}

From this short historical and town-planning analysis of ensemble of the Tula Kremlin it is possible to draw the following conclusions.

6.1 The short historical and town-planning analysis of the Tula Kremlin showed that restoration of initial shape of all ensemble is impossible as its historical and cultural value is represented only by defensive constructions (walls and towers of the Kremlin) and basic planning elements (the directions of the main streets and an arrangement of Cathedral Square).

6.2 The reconstruction of the Tula Kremlin made within the Federal target program tends to create a generalized image including elements belonging to various stages of historical and architectural formation of the ensemble. Similar approach will not provide reconstruction of initial identity.

6.3 In the history development of the Tula Kremlin the potential possibility of development and inclusion in it structure of new objects is placed. Therefore creation of "atrium" in a northeast part of the territory of the Kremlin can't be arguable.

6.4 I consider that creation of the uniform space uniting buildings of the first Tula power plant and the yard formed by them will lead to the reconstruction of the lost historical integrity of ancient ensemble and create new opportunities of use of a historical kernel of the ancient Russian town [17].

\section{Acknowlegements}

The authors express his gratitude to the historian of architecture, a member of the Union of Architects of Russia Tatiana Mikhailovna Khalturina for providing graphic and analytical materials on the subject of this study from a personal archive.

\section{References}

1. A. Sharifi, Y. Yamagata, Resilience-Oriented Urban Planning, Lecture Notes in Energy, 3-27 (2018)

2. C. Silvestru, T.U. Wien, Proceedings of the Digital Heritage 2013 - Federating the 19th Int'l VSMM, 10th Eurographics GCH, and 2nd UNESCO Memory of the World Conferences, 695-698 (2015)

3. O.A., Pastukh, Stages of town-planning development of Tula in the 16-20th centuries: Bulletin of Civil Engineers 6(53), 30-36 (2015) 
4. O.A. Pastukh, Master's thesis (St. Petersburg state architectural and construction university, St. Petersburg, 2016)

5. On modification of the decision of the Tula City Council of June 20, 2007 No. 32/676 "On the approval of the Master plan of the municipality the city of Tula

6. Federal Law of Russian Federation. About introduction of amendments to the Federal law "On Objects of Cultural Heritage (Historical and Cultural Monuments) of the People of the Russian Federation" and separate acts of the Russian Federation, http://docs.cntd.ru/document/420327052

7. URL : http://docs.cntd.ru/document/902335243

8. URL : http://docs.cntd.ru/document/901820936

9. URL : http://docs.cntd.ru/document/423846108

10. T. Mikhaylova, D. Parshin, V. Shoshinov, A. Trebukhin, Voronezh Web of Conferences 33, 01033 (2018)

11. M.P. Gatti, Maintenance, reconstruction and prevention for the regeneration of historic towns and centers (2018)

12. R.W. Khalaf, World Heritage Context Historic Environment: Policy and Practice 9(1), 39-52 (2018)

13. W. Heitmeyer, R. Anhut, Bedrohte Stadtgesellschaften-Soziale Desintegrationsprozesse und ethnisch-kulutrelle Konfliktkonstellationen (Weinheim, 2000)

14. S. Golovina, V. Murgul, Procedia Engineering 117, 883-890 (2015)

15. S. Golovina, S. Kanyukova, MATEC Web of Conferences 106, 01008 (2016)

16. V. Murgul, N. Vatin, I. Zayats, Procedia Engineering 117, 824-829 (2015)

17. Venice Charter for the conservation and restoration of monuments and landmarks, 1964 (Venice, revisited, 2009) 